\title{
THREE AMERICAN VENTURES IN SUMMARY CIVIL PROCEDURE
}

\author{
ROBERT WYNESS MIMLAR
}

The term "summary" as applied to civil procedure had its origin in the summatim cognoscere of the Roman Law. In the late Middle Ages it was applied by the Italian jurists to that simplified and abbreviated form of procedure prescribed by the decretal Saepe contingit (1306) of Pope Clement V, which came to form the substratum of most of the modern Continental systems, as well as in considerable measure of the Anglo-American chancery and admiralty procedures. Briegleb, in his classic study, assails the correctness of this application ${ }^{1}$ on the ground that the Roman summation cognosccie was not a merely simplified and abbreviated version of the ordinary procedure, but a form characterized by a provisional and incomplete hearing and eventuating in a more or less provisional order, $=-a$ form, that is to say, to which our proceeding on application for temporary injunction would offer a fairly close analogy. According to his view, the curtailed ordinary form is not a "summary procedure" in any true sense, but one which is much more accurately denoted by the name "planary," "bestowed upon it by some of

Editor's Note: In editing this article the YALE LAW JoUnNal has abandoned its usual form in deference to the vishes of the author.

1 Breigleb, Einleitung IN die Theorie der sumamischer Prozesse (1859) 12-13. Such use of the term began in the secular law. Ibid 79. It appears in legislation and treaties of the Italian communes antcdating the Clementina Saepe. 2 Salviolr, Storia Della Procedura Crvme e CrisuNALE (1927) 330.

2 "As, for example, where application is made for the granting of the bonorum possessio ex edicto Carboniano or ventris nomine, or for a preetorian cautio or for the provisional award of aliment, or, again, where there is involved the anticipation of an action for the purpose of obviating the prejudice feared from its not being brought until a later time, or the postponement of a cause until after the disposition of another more important one (evc. praejudicii), or the duty of answering an interrogatory propounded in jure, or, finally, where the matter in question is the mere exhibition of a thing in controversy or the surrender, on application of one asserting ownership, of a thing which had been pledged to the person presently in possession." WeTzell, SYSTEar DEs onoestulches CIVILPROCEsSEs (3d ed. 1878) 303. See also Wenger, INSTITUTIONER DES RÖMIISCHEN ZIVILPROZESSRECHTS (1925) 315-\$16.

3 BRIEGLEB, op. cit. sitpra note 1 , at 12, 79-80.

4 "Planarius processus," from "de plano." "Simplicitcr et de plano, ao sine strepitu et figura judiciz." CLEMr. SAEPE and preceding papal legislation. See BrIEGLEB, op. cit. supra note 1, at 15 et seq., 79 et seq.; SALnoLr, op. cit. supra note 1 , at $332-383$. 
the fourteenth century jurist, or "expedited" (schleunig) employed by Briegleb himself. Nevertheless, the term "summary" became firmly established in Continental usage, as applicable to both sorts of variant procedure: namely, to that which differed from the ordinary form only in its elements of simplicity and abridgement, as well as to that which was guided by the principle of the Roman summatim cognoscere. In our own system the term is familiar enough, but has never had the same extensive field of application or found as its subject the same organized structure as on the Continent. Blackstone's only reference to summary procedure is in the matter of criminal jurisdiction, whose proceedings he distinguishes as regular and summary. The latter, in addition to common law proceedings for contempt, comprise certain statutory proceedings wherein "there is no intervention of a jury, but the party accused is acquitted or condemned by the suffrage of such person only, as the statute has appointed for his judge." : At common law, therefore, there was no proceeding of a purely civil nature to which the term was applied. Statutes, however, have everywhere provided, for particular cases, civil proceedings wherein expedition is sought by means of deviation from the ordinary rules in respect of process, pleading or mode of trial. To these, by common consent, the term "summary" has been extended. The reason for departing from the ordinary rule varies with the case: sometimes this departure is because of the concrete loss attendant upon delay, as in the case of dispossessing tenants wrongfully holding over; sometimes it is because of the official character of the defendant, as in the case of certain demands against sheriffs and other public officers; sometimes it is because of the public interest especially involved, as in the case of collection of taxes; sometimes, again, it is because of the greater degree of moral wrong attaching to the non-payment of a debt, as in the case of a surety suing his principal for reimbursement. With these individual instances of summary procedure the Anglo-American law has in general been content; it usually admits generic forms of abridged procedure for its inferior courts, but has been reluctant to provide, for administration by the court which administers the ordinary procedure, any collateral system of variant rules applicable to broad classes or groups of cases-such, for example as the procédure sommaire of the modern French law, or the so-called "regular-indeterminate" summary procedure of the German common law. ${ }^{B}$ Yet the annals of procedure in America are not without instances of a contrary tendency, and it is of three experiments in this direction that we would here

\footnotetext{
54 BL. CoMm. $* 280$.

- For these see Engelmann-Mildar, History of Continental Civil, Procedure (1927) 578, 768.
} 
briefly speak. All three date from the period closing with 1850 -a period fruitful for American procedure not only because of the emergence of the New York Code of 1848, but also because of a host of smaller but highly significant reforms whose history has been largely overshadowed by the commanding figure of that Code. Two of the three measures in question now belong to the realm of things forgotten, but the third continues in active life as an integral part of the procedural system in two important jurisdictions.

THE SOUTH CAROLINA SUMMARY PROCESS OF 1769

In South Carolina a local administration of justice was slow of achievement. Except for the brief and unsuccessful career of certain county and precinct courts established in 1721, it was not until 1768-nearly a century after the first settlement - that steps were taken to change the existing situation under which "Charlestown was the source and centre of all judicial proceedings." $s$ This meant that all common law civil business, other than that falling to the justices of the peace, was dealt with by the Court of Common Pleas sitting at the provincial capital. But by 1768 the increase of population in the outlying districts was such as to render a reform imperative, and in that year the Assembly adopted an act providing for a system of circuits to localize the trial of both civil and criminal causes, and otherwise re-regulating the judicial organization of the province. ${ }^{3}$ This act, however, encountered opposition on the part of the Lords of Trade and was rejected by the Crown on the ground that, in making, as it did, the judicial tenure dependent upon good behavior, instead of His Miajesty's pleasure, and rendering the appointment of sheriffs a purely provincial matter, it constituted an invasion of the royal authority, being, indeed, in the former regard, "indecent and disrespectful to His Majesty." But, in the following year, the legislation was reenacted in such form as to obviate the objections in question and was definitively sanctioned by the King in Council on November 29,1769 . Because of its own provision postponing its operation until the completion of the court-houses and prisons necessary

7 W. R. Simth, South Garolina as a Royal Province (1908) 145-146; WhITNEY, GOVERNMIENT OF THE ColoNeY OF SOUTH CAroLnA (189j) 13 Johns Hopkins University Studies 83.

s 2 Ranisay, History of South Carolina (1S09) 125.

9 "An Act for establishing Courts, building Gaols, and appointing Sheriffs and other officers, for the more convenient administration of justice in this Province," April 12, 1768. 7. S. C. STAT. 197. 
for the new system, the act did not go into effect until November 5,1773 , pursuant to proclamation of May 19, 1772.10

The progress of this legislation from its inception to its approval forms an interesting episode in the history of the relations between the British Crown and the American Colonies, but what concerns us here is the innovation which it accomplished in the field of procedure. Under the terms of the act it was made lawful for the judges of the courts thus established:

"to determine, without a jury, in a summary way," on petition, all causes cognizable in the said courts, for any sum not exceeding $\$ 20$ sterling, except where the title of lands may come in question: ${ }^{12}$ In which suit the plaintiff and defendant may have the benefit of all matters as if the suit were commenced in the ordinary forms of common law or equity, and the said judges are hereby required so to do, and to give judgment and award execution, together with costs, against the body or goods of the party against whom the same shall pass." It was also provided that "in case both parties shall desire to have the cause tried by a jury, or on application of either party, at his own expense, then the said judges shall immediately order issue to be joined, and the said cause to be tried by the jury impaneled at such courts." And it was further declared "that the said petition shall contain the plaintiff's charge or demand, plainly and distinctly set forth: a true copy whereof shall be personally served or left at the defendant's usual and notorious place of abode, by the sheriff or his deputy $* * *$ twenty days before the sitting of the said court." ${ }^{13}$

10 SMITH, op. cit. supra note 7, at 133-141; MCCRADY, Historx of Soutu Carolina UNDER the RoYal Government, 1719-1776 (1899) 639, 642. The Act of 1769 does not appear in the South Carolina Statutes at Large (see note to Nevils v. Hartzog, 4 Rich. L. 552, 553 (S. C. 1851)). So much of it as remained in force in 1790 , including the provisions relating to the summary process, is printed in GRIMKE, PuBLIC LAwS of THE STATE of Soutr CARolina (1790) 268-273. These provisions are also incorporated in 1 Brevard, Alphabetical Digest of the Public Statute Law of South Carolina (1814) 221.

11 Mr. Lamb, counsel for the Board of Trade, had criticized this part of the Act of 1768 on the ground that the pecuniary limit was too high. SMrTH, op. cit. supra note 7, at 136. But "the Lords of Trade got over the objection of $\mathrm{Mr}$. Lamb to the summary juxisdiction clause as a law of the same sort obtained in Ireland." MCCRaDY, op. cit. supra note 10, at 639 .

12 In consequence of the act of 1824 concerning Justice of the Peaco courts, the summary jurisdiction thereafter applied only where the demand exceeded \$20. Allen v. Singleton, 1 Rice 289 (S. C. 1839).

${ }^{13}$ Act of 1769, \& VI: Grimke, Public Laws of South Carolina (1790) 270; BREVARD loc. cit. supra note 10.

It is not improbable that this legislation was suggested by the Virginia statute of 1727 , re-enacted in improved form in 1748, establishing a proceeding by petition and summons for small debt causes. The act of 1727 (4 VA. SrAt. (Hening) 195-196) provides that "it shall and may bo lawful to and for the justices of any county court to hear and determine all suits *** for any debt or demand due by judgment, obligation, 
Such was the legislative basis of what came to be known as the South Carolina "summary process"-an expression constantly abbreviated to "sum. pro." On this basis there was built up a form of procedure admirably adapted to the purpose ${ }^{14}$ for which it was intended, and, in view of the general course of Anglo-American procedural reform, one remarkable for its precocity. The principles of the system as thus developed were as follows:

(a) In lieu of formal writ ${ }^{15}$ and declaration there was employed the petition provided for by the act. In this the averment of claim seldom needed to be more than the statement of a legal conclusion. Thus, in an action against the indorser of a promissory note, it was held sufficient to allege that the defendant "is indebted as indorser," without any mention of dishonor by the maker, the court observing that in this form of proceeding, "the plaintiff has always been permitted to state his case in the most concise manner." "10 On another occasion, it was said that

or account, for any sum or sums of money or tobacco, of the value of twenty shillings sterling or two hundred pounds of tobaceo, and not escecding the sum of five pounds current money or one thousand pounds of tobacco, by petition. And the said justices are hereby authorized and required, and shall have full power and authority so to do, and to award execution thereupon." Summons is to be issued upon the filing of the petition and service to be effected by delivery of the summons with a copy of the petition. If the defendant fails to appear, the justices are to "determine the cause upon the evidence produced, or dismiss the suit, as to them shall seem just." If, appearing, he puts in his "answer or plea," or fails to plead, then "the said justices shall instantly determine the cause, in a summary way, upon such evidence as shall be given, and shall give judgment according as the very right of the cause and matter in law shall appear unto them, without regard to form, or want of form. * * * In which proceedings the defendant shall have the bencit of all matters in his defence, that he might have had, if he had been sued in the ordinary forms of law."

By the act of 1748 (5 VA. STAT. (Hening) 499-500) which contains the express declaration that the proceeding is to be had "without the solemnity of a jury," it is provided that the petition shall state "whether the debt arises by judgment, obligation, or other specialty, or by account," in which last case a copy of the account is to be filed with the petition, and "that the court shall not admit of any delay in the determination of any suit brought by petition till another court, unless good cause be made to appear for such delay." This act also extends the proceeding to actions of detinue and trover.

14 In Hughes v. Phelps, 1 Brev. 81, 82 (S. C. 1802), it is said that "the act must have had two principal objects in view: 1 . The speedy determination of trifling controversies. 2. The determination of such suits with as little expense to the parties as possible."

I5 It appears that the petition in its character of process required the seal of the court to be affixed. "It was the opinion of the majority of the court in this case that a summary process ought to be cealed as a writ; and that it is a judicial process." Ibid. 81.

16 See Hilburn v. Paysinger, 1 Bail. 97, 98 (S. C. 1828). 
"it is not requisite in this jurisdiction to set out the cause of action in the body of the process with technical precision: it is usually stated in general terms, referring to an account, contract, or other writing, indorsed or annexed, for further specification." 18

This indorsement or annexing, in fact, was a requirement established by rule of court in the case of any "deed, note, open account, or other writing." 18

(b) By informal rule of court adopted in 1801,10 the defendant was required to make his defense at the sitting of court to which the process was returnable. This did not exclude a continuance for good cause, but denied to the defendant the right which he had in the ordinary procedure of imparling to the second court as a matter of course. ${ }^{20}$

(c) As regards the defendant's allegations, it would appear that at the outset this form of proceeding was one "where all the pleadings were ore tenus, and where parties were heard on both sides, without reducing them to legal form." ${ }^{21}$ Notwithstanding that in 1801 the court had unmistakably called for writing in this regard, ${ }^{22}$ it seems to have been the general usage of the bar down to 1828 "to dispense with formal pleas." ${ }^{23}$ But in that year came a pronouncement to the effect that, under the act, a written plea, unless waived by agreement of the parties, was necessary to permit evidence of a special defense.

"The same necessity," it was said, "exists as well in this as in the higher jurisdiction of the Court, for appraising the plaintiff of the grounds of the defense, and when that defense consists of a matter pleadable at law, I cannot conceive of any forms mor'e convenient or appropriate than those established by the practice of the Courts: And if a case should occur in which these would not apply, and that might well happen, as this is a species of equity jurisdiction, something in the form of an answer would be admissible." 24

17 See Parker v. Martin, 1 Bail. 138, 139 (S. C. 1828). "If the party in a short way state his claim to demand money, as a debt, or as a compensation for an injury, and enough appears to apprise the party of the mattor to which he is called to answer, it is generally sufficient." Caldwoll v. Langford, 1 McM. 275, 277-278 (S. C. 1841). But of. McDaniel v. Scoggins, 2 Mill 227 (S. C. 1818).

18 Rules of May 7, 1814, No. xxxvii, in 1 Mill xviii (S. C. 1817) ; Hagood v. Mitchell, 1 Bail. 124 (S. C. 1828); Parker v. Martin, supra note 17.

10 Strange v. Evans, 2 Bay 327 (S. C. 1801).

20 Ibid.; Hughes v. Phelps, supra note 14.

21 Argument of counsel for plaintiff in Strange v. Evans, supra noto 19.

22 Hughes v. Phelps, supra note 14. But it is also said here that "it never was customary to make up any pleadings on summary process" (meaning formal pleadings). Ibid. 82.

23 See Bailey v. Wilson, 1 Bail. 15, 17 (S. C. 1828).

24 Ibid. 17, per Johnson, J. 
(d) Where a jury was demanded, the court, instead of waiting until the parties had arrived at an issue as in the ordinary course of pleading, exercised, under the terms of the act, the power of immediately ordering issue to be joined. In keeping with what has been said above,

"this issue need not be a formal issue, in every respect conformable to the pleading in other cases, but a plain simple denial or plea in writing etc.; for the judges are authorized to malse all necessary rules and orders for promoting the design of the legislature in passing this act." 20

(e) Pursuant to the act, the trial was by the court without a jury, unless a jury was demanded. It appears, however, that the right to a jury was rarely taken advantage of." ${ }^{20}$ To this result may have contributed the rule laid down in 1797 that in this form of proceeding the party electing to demand a jury was "bound by their decision or verdict, as much as he would have been bound by an award of arbitrators, against whom no misconduct could be alleged." 27

( $f$ ) A particularly striking feature of this procedure was the provision made for the examination of the parties by means of written interrogatories. In Dillon v. MCCue, ${ }^{28}$ decided in 1800 , it was said that, when common law rules of evidence fail, "the parties may then resort to equitable principles to supply the defects of the common law; that where there is no evidence to be procured, the defendant has a right to call upon the plaintiff to answer on oath, touching any matter known only to the parties themselves; and if the plaintiff refuses to answer, then to talie the matter pro confesso, or to move for a non-suit;" and that, for this purpose, the plaintiff ought to give the defendant a written notice specifying the points as to which answer was sought. This direction, by 1814, at the latest, had grown into a formal rule of court, in terms applicable to both parties:

"If the plaintiff in an action by summary process shall desire to have the benefit of defendant's oath, he shall state, in writing, the points to which he shall require his oath, and serve him with a copy thereof, with notice of such his intention, at least one day before the hearing of the cause; and defendant may either give his answer in writing, to be sworn to before the clerk, or ore tenus in open court; and if a defendant shall desire the benefit of the plaintiff's oath, he shall proceed to require it in the same manner." 29

\footnotetext{
${ }^{25}$ Hughes v. Phelps, supra note 14, at 82.

28 Reporter's note to "Process summary" 2 Bay at p. 585; argument of counsel for plaintiff in Strange v. Evans, supra note 19, at 327.

${ }^{27}$ See James v. O'Driscoll, 2 Bay 101, 103 (S. C. 1797).

282 Bay 280 (S. C. 1800).

${ }^{29}$ Rule XXXVI of Miay 7, 1814. I Mill swii-xviii (S. C. 1819).
} 
Authority for the practice in question appears to have been found in the clause of the act giving the party "the benefit of all matters" as if the suit had been commenced in equity." Moreover, it is not at all unlikely that Blackstone's quite remarkable criticism of the lack of means of discovery in common law causes ${ }^{31}$ had something to do with the result. But as to the form of discovery, there was obviously a wide departure from current equity practice. At the time in question that practice knew no such thing as interrogatories apart from the bill or as the reciprocal right of the defendant to discovery, otherwise than by means of a cross bill. This method of discovery is familiar enough to us today, but it was not until 1852, under the Chancery Practice Amendment Act of that year, that it was introduced in England ${ }^{32}$ and not until the Rules of 1912 that it passed into the equity practice of the Federal Courts. There is good reason, therefore, for believing that we have here the first instance in Anglo-American procedural history, not only of discovery grantable in common law actions, but also of the separate interrogatory, open alike to plaintiff and defendant, as the particular mechanism of discovery. What suggested the adoption of this form, other than its simplicity, we have no means of knowing. In view, however, of the French Huguenot element among the cultured classes of South Carolina, there is room for the conjecture that it was influenced by the French institution of interrogatoires sur faits et articles. Both under the Ordinance of $1667^{33}$ and the Code of 1806 , $^{34}$ this was a means whereby either party was entitled to demand the answer of the other to the points of fact articulated by the former in writing; like its progenitor, the Romano-canonical positions, it was entirely disconnected from the pleadings; and the interrogatories, pursuant to order of court, were served upon the party sought to be questioned, who at an appointed time appeared and answered them before the court or a delegated judge. While the present proceeding is simpler, the rule of court concerning it might well have been drafted in the light of the French practice.

Following the view taken in Dillon v. McCue, it was at the outset uniformly held that the right to compel an opponent's answers to interrogatories was conditioned upon the party's inability to prove his case in any other manner. ${ }^{36}$ Later,

${ }^{30}$ Holly v. Thurston, 1 Rice 282 (S. C. 1839).

313 BL. CoMm.* 382.

32 As to the precise manner of introduction under this act, see Langdall, Discovery Under the Judicature Acts, 1873, 1875 (1898) 12 HARv. L. Rפv.

151, 165 et seq.

33 Ordonnance civile, tit: $X$.

34 Code de Procédure Civile, Art. 324-336.

35 Brown v. Collins, 2 Bay 326 (S. C. 1801); Addison v. White, 2 Mill 
this doctrine was discarded and the answers placed upon an unconditional basis. ${ }^{36}$ Nevertheless, as it appears to have been conceived that the right to the equitable means of proof presupposed a default of common law means, the idea persisted that the party, in resorting to interrogatories, was in effect saying that he could not otherwise prove his case. As a result, while the party remained free to interrogate his opponent without any preliminary showing, ${ }^{37}$ and to offer or not offer the answers in evidence, ${ }^{38}$ the rule was that if he did offer the answers, resulting from an examination of the opponent upon the whole case, he was not permitted to introduce any other evidence."s Inssmuch as in making the answers, the defendant was not a witness, no cross-interrogatories were permitted, and when the answers were made orally there was no cross-examination. ${ }^{43}$ Failure to answer might result in a decree $p r o$ confesso or a non-suit as the case required.11 Allowance made for its peculiarities, the proceeding was governed by ordinary equity principles, since "the rule of Court was intended to assimilate these cases

369 (S. C. 1818); Wallace v. Norvell, 1 Bail. 125 (S. C. 1828); but sce Walker v. Mathaney, Harp. 187 (S. C. 1824).

36 Roche v. Chaplin, 1 Bail. 419 (S. C. 1850); Toomer v. Righton, Riley 263 (S. C. 1887) ; Brown v. Stroud, \& Rich. L. 202 (S. C. 1855).

37 Brown v. Stroud, supra note 36.

38 Henken v. Gramann, 2 Rich. L. 365 (S. C. 1846).

39 Brown v. Stroud, supra note 36; Harrison v. Dodson, 11 Rich. L. 48 (S. C. 1857). In the latter case it is said that the procecding is "exactly analogous to a bill for discovery, as ancillary to another suit." But the analogy fails to support the result reached, because, under such a bill, the plaintiff is entitled to the discovery, even "if it be merely cumulative evidence of material facts." STORY, EQUTrY PLannngs (10th ed. 1S92) $\S 324$, and note to $\$ 320$. In a previous case, Henlien v. Gramann, supro note 38 , at 367 , the court with more correctness had recognized that the plaintiff, under the equity practice, was confined to the use of the defendant's answer only where the jurisdiction of the court was involied to decide a purely legal claim on the ground that the facts necessary to its establishment were exclusively within the knowledge of the defendant [Russell v. Clark's Executors, 7 Cranch 69, S9 (U. S. 1812)] and that the jurisdiction of the court in the summary process "did not at all depend upon discovery." But the court in the eame case foreshadows the rule later established by saying, "If they had offered the answers, they might, perhaps, have been considered as having admitted that they had no other suficient evidence upon the matters concerning which they had interrogated the defendants, and so, from analogy to equity practice, they might have been prevented from contradicting the defendants whom they had made their witnesses." The analogy here attempted seems as objectionable as the former, and certainly the reference to the interrogated defendants as witnesses mistalies their true character.

10 Hill v. Denny, 1 Strob. 338 (S. C. 1847).

s1 Dillon v. McCue, supra note 28; Walker v. Mathaney, cupra note 35; Fullmore v. Cockfield, 2 Bail. 446 (S. C. 1831). 
to the practice in Chancery" ${ }^{42}$ and "there is nothing in the rule which favors the idea that the discovery to be obtained under it can be demanded in a case where the Court of Equity would refuse it." ${ }^{43}$

(g) It is clear that, under the construction given the act, the court, where occasion required, was accustomed to apply substantive equity principles in common law causes. Though the reported cases do not disclose any specific instance of this administration, there is plenty of evidence of its existence. Said counsel for the plaintiff in Cash v. Lyle 1807: ${ }^{44}$

\begin{abstract}
"This mode of proceeding is conformable to the proceedings in courts of equity $* * *$ and under the summary jurisdiction of the Court of Common Pleas, the equity of cases is considered as well as their legal merits; and decrees are often founded upon the equity of the causes in which they are given." 45
\end{abstract}

It is judicially taken "for granted that the district court in the exercise of its summary jurisdiction, on petition and process, may decide according to the rules which prevail in equity," that is to say, "when there is some equitable matter brought into the view of the court." 40 So, also, there is judicial reference to the process as "a new mode of proceeding, corresponding with the proceedings in equity or at law, as the particular circumstances of the case may require," ${ }^{47}$ as "a species of equity jurisdiction," 48 as "an equitable proceeding," 40 as a "quasi equity jurisdiction." " And there is unmistakable recognition that it was open to the defendant to plead an equitable defense. ${ }^{51}$ On the other hand, it is clear that the jurisdiction was not concurrent with that of the court of equity : an attempt made in 1821, by means of the summary process, to charge the separate estate of a wife, in the hands of her husband as trustee, with a debt which the former had incurred for the benefit of the separate estate, was met with the answer that the jurisdiction, under the terms of the act, extended only to "causes cognizable in the said Courts," that is to say, to the common law

\footnotetext{
42 Clark v. Meek, 2 Bail. 391 (S. C. 1831).

43 Holly v. Thurston, 1 Rice 282 (S. C. 1839).

442 Brev. 183 (S. C. 1807).

45 In the reporter's note to "Process summary," in the index to 2 Bay at p. 585 , it is said that in the summary process "the parties have all tho advantages of law and equity" and that frequently there will be found "the principles of both jurisdictions, in those small cases, blended togethor."

46 Harman v. Counts, 2 Brev. 476 (S. C. 1811).

47 Taylor v. Drake, 1 McCord 174 (S. C. 1821).

48 Bailey v. Wilson, supra note 23.

${ }^{49}$ Goodson v. Oliver, 2 Bail. 446 (S. C. 1831).

${ }^{50}$ Lewis v. Kemp, 6 Rich. L. 515 (S. C. 1832).

52 Bailey v. Wilson, supra note 23.
} 
causes constituting the jurisdictional field of the court of Common Pleas. ${ }^{52}$

(h) The final judgment was known as a "decree."

"The practice under the act has been for decrees to be pronounced in open court, viva voce, by the presiding magistrate, which are recorded in the clerk's book of the minutes of the proceedings of the court; and no other kind of decrees or judgments are usually given." 53

This record was the only one made, there being no expansion of it into a formal order.

"The minute of the judgment, or decree, made at the time that it is given in court, is the record of such judgment or decree and, though brief and informal, is a sufficient record to authorize the issuing of execution thereon." "st

(i) Employment of the proceeding was optional with the plaintiff. He might, instead, bring his suit in the ordinary form. But, in the absence of good reason for so doing, he was then entitled, in the event of success, to no more than the reduced costs of this form.

"Where one sues in the general jurisdiction, and offers no proof whatever of a sum beyond the limited jurisdiction, or where it appears, obviously, that the suit has been instituted wantonly, upon a fictitious demand, with a view to increase the costs, he shall recover only the costs allowed on summary process." 58

So regulated, the summary process was a conspicuous feature of South Carolina judicature for nearly a century. It came to an end in the unhappy days of Reconstruction, being superseded through the adoption in 1870 of the Code of Civil Procedure, modeled upon that of New York. The last reported case in which it was employed appears to be Goggans v. Turmipseed decided in 1868.57 Perhaps the benefits which it conferred have been realized quite as well under the provisions of the Code. Nevertheless, had the reform of civil procedure in South Carolina taken place under different conditions, it is certain that the change would have been less revolutionary, and the probability

52 Taylor v. Drake, supra note 47.

s3 Witherspoon, counsel, in Cash v. Lyle, supra note 44.

54 Per Trezevant, J., in Cash v. Iyle, supra note 44, at 185 . See also Foster v. Chapman, 4 McCord 291 (S. C. 1827).

55 Trowell v. Youmans, 5 Strob. 67 (S. C. 1850).

58 Furman v. Peay, 2 Bail. 612 (S. C. 1832); Nance v. Palmer, 2 Bail. 88 (S. C. 1831); Cambridge Association v. Nichols, 1 Trendw. 121 (S. C. 1812).

571 S. C. 80 (1868). 
is that some traces of the old proceeding would have been permitted to survive.

That proceeding deserves to occupy a notable place in the history of American civil justice. It constituted a courageous departure from traditional institutions, skillfully conducted and successfully accomplished. Its simple petition as a substitute for summons and declaration; its lack of emphasis upon the distinction between forms of action; its flexible requirements with respect to the defendant's pleading; its bestowal upon the court of power to direct an issue in jury cases; its accentuation of trial by the court without the intervention of a jury - all these represent ideas that we are accustomed to think of as belonging to a later day. So, too, the possibility which it afforded of applying equitable principles in common law actions, with its incident recognition of equitable defenses, and the introduction on its part of a competent system of discovery in these same actions, were long in advance of any other Anglo-American legislation on the subject.

\section{II}

THE KENTUCKY PROCEEDING BY PETITION AND SUMMONS OF 1805

We now turn to another example of the same kind of legislation, one of narrower compass and less adequate principles, which, nevertheless, found acceptance in a much larger territorial area. This originated in the Kentucky statute of December 26, 1805, entitled "An Act providing a summary mode of recovering debts." ss It was here provided that

"when any person holding a bond or note for the direct payment of money, shall desire to put the same in suit, he mayr do so by filing it with the clerk of any circuit court holding jurisdiction thereof, together with a petition purporting as follows: 'F. circuit, sct. A. B. plaintiff, states that he holds a bond or note (as the case may be) on the defendant C. D. in substance as followeth (here insert a copy of the bond or note); yet the said debt remains unpaid; wherefore he prays judgment for his debt, and damages for the detention of the same, together with his costs, etc." "50

If the plaintiff held as indorsee, he was to attend the setting forth of the instrument with the statement:

"On which is the following assignment or assignments (reciting these) whereby the plaintiff hath become the proprietor thereof, of which the defendant hath had due notice."

58 Littell, Statute LaW of Kentucky (1811) 319-21.

50 Act of December 26, 1805 § 1. .

co Ibid. § 2. 
Further provisions of the act were that "a copy of the petition shall be sent out with a summons annexed thereto, requiring the defendant or defendants to appear and answer the said demand, on the third day of the succeeding term;" that service was to be effected by the sheriff delivering a copy of the petition and summons to the defendant; ${ }^{11}$ that the "petition and summons shall not go to the rules, but the proceedings shall be in court, and shall be docketed to the third day;" $:$ that the petition "shall stand in place of a declaration" and "an issue may be joined as in an action of debt, on such a bond or note;" ${ }^{03}$ and that the employment of this proceeding, rather than the ordinary form, was to be optional with the plaintiff."s

"The evident object of the law," said the Court of Appeals in 1816, "was to give, in cases where there was a bond or note for the direct payment of money, a more speedy remedy than was then afforded by the tardy mode of proceeding at law; and the remedy was given in those cases only, because the bond or note furnished intrinsic evidence of the debt; and there was not as likely in such cases as in others to exist any extraneous matter of defense." 65

And it is also evident that, by providing the exact form of words to be used in the petition, the legislature intended, for the same reason, to furnish a means whereby the litigant could commence his own suit, without the aid of counsel. ${ }^{\circ}$

The proceeding as thus established experienced later two statutory modifications. In 1827 it ceased to be necessary to serve the defendant with a copy of the petition, service by summons alone being made sufficient; ${ }^{67}$ and in 1837 the particular provision concerning expedited trial was displaced by the requirement, applicable also to actions of debt on records and specialties, that the suit be "docketed for the first day of the term, and stand for trial on said day; but if defence be made, the

61 Ibid. $\$ 3$.

62 Ibid. \$ 4 .

63 Ibid. § 6.

64 Ibid. \& 8.

65 Kentucky Insurance Co. v. Hawkins, 4 Bibb 470 (Ky. 1816).

66 $C f$. in this regard the Tennessee statute of Nov. 20,1811 , providing that the plaintiff or defendant may enter his "own plea, and defend his, her or their own cause, and if the cause of action is founded on a specialty, note or liquidated account (signed by the parties) no declaration shall be required of the plaintiff, but the suit shall be tried in a summary way without pleading in writing, and no instrument of writing ghall be lost or destroyed for want of form, if it contains sufficient substance, any law to the contrary notwithstanding. Provided, Nothing herein contained shall be so construed as to prevent any defendant to file his pleas in writing either by himself or attorney." Acts of 1811, c. 114. 2 TENN. Laws (Scott, 1821) 71.

o7 Acts of 1826-1827, 126; Gearhart v. Olmstead, 7 Dana 441 (Ky. 1833). 
case shall stand for trial on the second day of the court, as though set for trial on that day." es

In the construction placed upon the act by the Court of Appeals there was a fair furtherance of its objects. Thus, in a suit against a corporation it was said with reference to the statutory words, "the plaintiff holds a note on the Newport Manufacturing Company," that

"this comprehensive allegation-as in other cases of petition on notes-imports every fact (consistent with the tenor of the writing) that is necessary to show that the note is genuine, and binding 'on' the defendant." ${ }^{6}$

It was held that the proceeding lay against executors on their testator's instrument, ${ }^{70}$ lay in favor of a corporation ${ }^{71}$ and permitted of the joining in suit of a number of notes ${ }^{2}$-conclusions which too ritualistic an observance of the statutory form of petition would have denied; that it lay also where the note was written in a foreign language; ${ }^{73}$ and that a paper stating that the defendant had "borrowed" from the agent of the plaintiff a specified sum was a note within the meaning of the statute. ${ }^{74}$ On the other hand, it was insisted that the petition on its face disclose a cause of action. ${ }^{75}$ Moreover, "where the obligation to pay accrues upon the happening of a contingency, depends upon a condition to be performed by the plaintiff, or any like matter" requiring to be specially alleged, then the proceeding could not be maintained, since the statute left no room for any such allegation. ${ }^{76}$ As this doctrine was otherwise expressed,

"the statute authorizes such remedy only where the writing is evidence, so directly and unequivocally on its face, of a debt due in money, as that no averment is necessary to show that the plaintiff is entitled to the debt demanded." 77

68 Acts of 1836-37, 279.

${ }^{60}$ See Commercial Bank v. Newport Mfg. Co., 1 B. Mon. 13, 16 (IY. 1840).

70 Moore's Executors v. Gwathmey, 2 Bibb 334 (Ky. 1811) ; Moore's Executoŕs v. Russell, 2 Bibb 443 (Ky. 1811).

71 Kentucky Insurance Co. v. Hawkins, supra note 65.

72 Bliss v. Branham, 1 J. J. Marsh. 200 (Ky. 1829).

73 Hartman v. Welz, 1 B. Mon. 242 (Ky. 1841).

74 Harrow v. Dugan, 6 Dana 341 (Ky. 1838).

75 Kincaid v. Higgins, 1 Bibb 352 (Ky. 1809) ; Brittenham v. Cummins, $1 \mathrm{Bibb} 487$ (Ky. 1809).

re Kincaid v. Higgins, supra note 75.

77 See Pool v. McCaughan, 6 T. B. Mon. 335, 336 (Kу. 1827).

In 1837 an act was passed rendering this proceeding applicable to suits against the drawers, indorsers and acceptors of bills of exchange and making these parties thus answerable jointly and severally to the holders. A new form of petition was prescribed, applicable to this situation, but, evidently in view of the doctrine above noted, it was also provided that 
Nevertheless, the court seems to have been quite liberal in dispensing with the necessity of such an averment. Thus it countenanced the proceeding in one case where one of two joint obligors had died prior to suit and recovery was sought from the survivor, ${ }^{78}$ and, in another, where a number of persons were sued as members of a partnership on a note signed "Castleman \& Co." 79 To be sure, in the former of these cases, the court took the view that no averment would have been required even in a common law declaration, but this seems rather a twisting of the orthodox rule for the purpose in hand. Again, where the note sued on read: "Due F. K. one hundred thirty-nine pounds one shilling, the freight to be deducted out of it," it was held that the deduction was a matter of defense, not requiring notice in the petition. ${ }^{\text {so }}$ And, finally, we encounter the holding that a replevin bond is an instrument for the direct payment of money and will support the proceeding. ${ }^{81}$ The ground of the last result does not appear, but certainly there might here be invoked the analogy of the earlier practice at common law in which the declaration counted only upon the so-called "money part" of the bond, leaving the condition to be developed of record by the defendant. But, when it came to the matter of the medium of payment called for by the obligation, the court at all times preserved a stricter attitude. Since the statute allowed the proceeding only in case of instruments for the pryment of money, nothing short of lawful money of the United States would satisfy this requirement. ${ }^{82}$ Nor was the proceeding recognized as proper where the undertaking was to pay money or something else, in the alternative, ${ }^{83}$ or even to pay money plus something else..$^{\text {st }}$ Taken as a whole, however, it must be said that

"the plaintiff may make any averment at the bottom of the petition, which he shall deem necessary to sustain his case." Acts of 1836-87, 41-43.

The same Act created a like joint and several liability, enforcible by this remedy, under a prescribed form of petition (which, also, was subject to the last mentioned provision) in favor of "any banls incorporated by this Commonwealth, who shall hold a promissory note, negotiable and payable at any incorporated bank, and discounted by the banl holding the same, or $* \approx$ any indorser who shall have talien up any such discounted note," and "against the drawers and previous indorsers."

rsVaughn v. Halstead, 4 Bibb 468 (Ky. 1816).

79 Kinsman v. Castleman, 1 T. B. MIon. 210 (Ky. 1824).

${ }^{80}$ Kalfus v. Watts, Litt. Sel. Cas. 197 (Ky. 1814).

s1 Sanders v. Outten, 1 J. J. Miarsh. 488 (Ky. 1829).

82 Chambers v. George, 5 Litt. 335 (Ky. 1824); Fleming v. Campbell, 1 J. J. Marsh. 499 (Ky. 1829).

83 Louden v. Kenney, 1 Bibb 330 (Ky. 1809); Townsend v. Burgher, 7 T. B. Mon. 224 (Ky. 1828).

8s Wright v. Coleman, 4 Bibb 252 (Ky. 1815). 
the decisions display a comparatively generous attitude toward the act and its purposes. ${ }^{\mathrm{g5}}$

It will be seen that the variation from the ordinary procedure presented by the remedy in question consisted first, in the simpler and ready-made manner of pleading the claim and commencing the suit; secondly, in the possibility of a speedier trial. As regards the defendant's pleadings, however, and the further steps in the cause there was no dispensation from the rules applicable to common law causes in general. Yet with these modest advantages, the proceeding seems to have proved a highly popular one. The reported decisions of the Court of Appeals down to the 10th B. Monroe (1850) show its constant employment, and in Moorehead's work on Kentucky civil practice, published in $1846,{ }^{86}$ some fifteen pages are devoted to its treatment. It disappeared only with the general reform of civil procedure inaugurated by the Code of Practice of 1851.

But the proceeding found adoption beyond the borders of Kentucky. It appeared in sundry other jurisdictions, usually with slight variations from the Kentucky model. The first of these seems to have been Alabama, which established the proceeding by Act of December 20,1820.87 Here, for the Kentucky direction as to expedited trial, there is substituted the less urgent provision that the issue joined "shall stand over to, and be tried at, the next term of the court $: * *$ unless a trial is had at the first term by consent of the parties." ${ }^{88}$ If the Supreme Court reports are any criterion, the proceeding was not highly favored in this State; only some half dozen cases are there identifiable as having been brought in this form. ${ }^{s 9}$ Nevertheless, it continued to be available until the taking effect of the Code of 1852 .

Missouri was the next state to follow the Kentucky example, this by Act of January 17, 1825.90 The latter was a close copy of the original statute with two additions: ${ }^{\text {II }}$ (1) the remedy was made to apply to bonds or notes "for the direct payment

85 For other decisions see Moorehead, Practice in Civil ACTions and Proceedings at LaW in Kentucky (1846) 524 et seq.

86 The work last cited.

${ }^{87}$ Sections 1-5, 12 of "An act to regulate the proceedings in suits at common law." Toulmin, Digest of THE LAwS OF ALABAMA (1823) 478 et seg.

88 Act of December 20, 1820, § 5 .

89 Brahan v. Collins, Min. 169 (Ala. 1823); Gilbert v. Lane, 3 Port. 267 (Ala. 1836); Norwood v. Riddle, 9 Port. 425 (Ala. 1839); Hounshell v. Phares, 1 Ala. 580 (1840); Ice v. Manning, 3 Ala. 121 (1841); O'Neal v. Garrett, 3 Ala. 276 (1842).

80 "An Act simplifying proceedings at law for the collection of debts." 2 DIGEST OF THE LAWS OF MISSOURI (1825) 620-21.

91 It contained also the insignificant variation that the proceedings wero to be docketed to the second, instead of the third day of the term. 
of property or money;" (2) provision was made holding the defendant to bail by means of a copias-which could not be done under the Kentucky act.92 Ten years later this legislation was re-enacted in a form giving evidence of much more skillful draftsmanship than the original. Retaining the extension of the remedy to cases where the medium of payment is property, this Act of $1835^{93}$ calls the proceeding a "petition in debt." Under its provisions service is effected by summons, without a copy of the petition, or by capias; the defendant, as a rule, is to plead on or before the second day of the term and "suit in such cases shall be determined at the same term, unless continued for good cause."

The course of decisions under these Missouri acts exhibits no radical difference from that in Kentucky. There was at first some confusion as to the possibility of adding to the statutory form. Thus, it was held that an administrator could not sue in this form without an allegation showing his right, ${ }^{0 s}$ and similarly that, in the case of a note signed in a partnership name, there must be an averment identifying the defendants as the persons who composed the partnership.95 On the other hand, where a petition filed by an administrator set forth a note bearing date after the date of his letters, whereof profert had been made, it was said that "the form prescribed by the act precludes the plaintiff from making any statement of the true time when the instrument was executed," but that, as he might be able to explain the inconsistency,

"whatever he might have been required to state in a declaration at common law that is incompatible with this statutory mode of proceeding, he must be allowed to prove on the trial, if the defendant by his plea elect to put it in issue." 20

Later, there was an express recession from the cases inconsistent with the last mentioned, this in a suit against a partnership, where the court said that

"the statement in the petition, that the plaintiffs are the legal owners of the note or bond, includes the averment that the note set out was executed to the plaintiffs by the partnership name." ${ }^{97}$

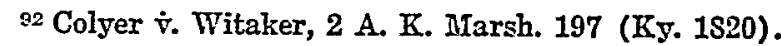

${ }_{93}$ "An act for the speedy recovery of debts due on bonds and notes," approved March 14, 1835. MIo. REv. STAT. (1835) 449.

94 McGill v. Leduc, 3 Mo. 398 (1834) ; Bailey v. Ormsby, 3 MIo. 580 (1894).

${ }_{95}$ Tabor v. Jameson, 5 MIo. 495 (183S); Dyer v. Sublette, 6 MIo. 11 (1839).

s6 Hamilton v. Stewart, 5 Mo. 266, 268 (1838).

g7 Woods v. Hunt, 6 MIo. 163, 164 (1839). To the same efrect is Middleton v. Atkins, 7 IIo. 184 (1841). 
There thus came to be unqualified acceptance of the Kentucley doctrine that the petition did not admit of "averment." os Moreover, the same significance as in Kentucky was attached to the words "direct payment," it being held as there that the proceeding could not be maintained on a note by which the defendant undertook to do certain acts in addition to the payment of money. ${ }^{92}$

The flourishing period of the proceeding in Missouri is that covered by Volumes 2 to 7 of the Missouri Reports, that is to say, between 1827 and 1842. During the remainder of its life, which ended with the adoption of the Code of 1849, it seems to have been seldom resorted to.

Illinois, in its turn, succumbed to the attractions of the proceeding, adopting it by Act of February 25, 1833.100 This statute is an almost exact reproduction of the Missouri act of 1825, including the direction that the suit shall not "go to the rules," -a regulation which was probably never appropriate to the Illinois practice. For this reason, in all likelihood, the direction in question was omitted in the Revised Statutes of 1845,101 where the act appears without any provision concerning expedited trial. A decision in $1839^{102}$ evidences that the Supreme Court was alive to the origin and purposes of the proceeding. Said the court, per Browne, J.,

"They have a statute in Kentucky very similar to ours, which has always been liberally construed by their courts. It seems to me one of the objects of the statute was to enable any person to bring his own suit. I am strengthened in this opinion from the circumstance of the form of the petition being laid down in the statute. The statute is intended to give a more speedy remedy than was afforded by proceedings at law."

Despite this good beginning, it can hardly be said that the court, in the upshot, was disposed to view the proceeding with a very frendly eye, since of some six cases in which questions relating to this form were dealt with, two disclose a reversal of the lower court's judgment on the ground that the verdict and judgment were in terms of damages instead of debt. ${ }^{103}$ The proceeding, here,

\footnotetext{
98 Curle v. McNutt, 6 Mo. 495, 496 (1840).

${ }^{99}$ Curle v. Pettus, 6 Mo. 497 (1840); see, however, Casey v. Barcroft, 5 iIo. 128 (1838).

100 Gale, Public and General Statute Laws of Illinois (1839) 638. 539.

101 ILL. REV. STAT. (1845) c. 83, §§ 33-37.

102 Evans v. Landon, 3 III. 53 (1839).

${ }^{103}$ Jackson v. Haskell, 3 Ill. 565 (1840); Heyl v. Stapp, 4 Ill. 96 (1841). The other cases referred to besides Evans $\nabla$. Landon, supra noto 102, aro Duncan v. McAffee, 3 Ill. 559 (1840); McConnel v. Thomas, 3 Ill. 313 (1840), and Douglas v. Whiting, 28 Ill. 362 (1862), the last being an
} 
enjoyed nothing like the vogue it had attained in Kentucky and Iissouri, and the act seemingly had become virtually a dead letter long before it was dropped from the statute-book in the revision of 1874 .

Another state to borrow the proceeding was Arkansas. The statute giving place to it, approved November 29, 1837, was evidently modeled on the revised Missouri act of 1835 . It exhibits, however, some differences in detail. The remedy is made applicable to any "bill," as well as to notes and bonds, "for the direct payment of money or property ;" a copy of the instrument and assignments, instead of the originals, is to be filed with the petition; and apparently in view of the earlier Missouri decisions, with reference to suits by personal representatives, two sections are interpolated authorizing the use of the remedy by executors and administrators and providing a separ. ate form of petition for this case. No expedition of trial is contemplated, it being declared that the suit "shall be prosecuted to final judgment and execution in the same manner as if it had been commenced in the ordinary form." 18 In one of the first cases of the proceeding which came before the Supreme Court, it is curious to note that counsel for the plaintiff, while arguing for the sufficiency of the petition, took occasion to ventilate their private opinion of the institution in question, by observing that

"we regard the whole matter of petition and summons as a useless and pernicious innovation on established forms and as calculated more frequently to thwart than to forward justice." acs

As to the decisions themselves, there deserves to be mentioned the virtual nullification of the act so far as relates to instruments payable in property. This occurred in Hitchell $v$. Walker (1842) ${ }^{106}$ where suit had been brought upon a note "to be paid in Arkansas State Bank paper." The court held that the proceeding could not be maintained, because what the statute provided was a summary mode of recovery in an action of debt, and debt at common law would not lie upon an instrument of the present kind. That the action was one in debt was of course correct, as had been conceded in other jurisdictions, but apparently it never occurred to the court that it was open to the legislature to enlarge the compass of the action of debt, and that this had actually

action of ejectment involving a collateral review of proceedings by petition and summons instituted in 1857.

104 ARK. Rev. Stat. (1837) 152-153.

10.5 Dudley v. Smith, 2 Ark. 365, 367 (1840). This observation in all likelihood proceeded from the picturesque Albert Pike, as Pike and Sutton are mentioned as counsel for the plaintiff.

1084 Ark. 145 (1842). 
been done in the present instance by the express extension of the remedy to instruments payable in property. We may note also the insistence upon the doctrine forbidding addition to the statutory form. "The statute," it is said in Thompson $v$. Shreve (1866)107 "admits of no material averments other than those, in substance, which it prescribes." The cases relating to the remedy occur from the $2 d$ down to the 25th volume of Arkansas Reports and, from their respectable number, would argue that it was in fairly common use. Certainly, it had not been in any sense laid aside prior to its supersession by the Code of Practice in Civil Cases enacted in 1868.

Some two years after Arkansas had received it, the institution in question was introduced in the then territory of Iowa. Here it formed the subject of certain sections in the Act of January 25, 1839.108 These appear to have been based upon the Illinois act or the Missouri Act of 1825, as like either, they follow the Kentucky phraseology, but contemplate an instrument payable in property as well as one payable in money. They contain no special provision looking to expedition of trial. Since the general reform of civil procedure in this jurisdiction took place in 1851, through the adoption of the Code of that year, our proceeding had here a short lease of life. In the single case in which it came to the attention of the Supreme Court-Jacobson v. Manning, decided in $1850^{100}$ - the court treats it with respect but seems rather to apologize for doing so, saying that

"when the proceeding under the statute $: *:$ is adopted by a plaintiff, if he proceed in the manner and form thereby prescribed, he must be sustained by the courts, however subversive of the common law the procedure may be."

Finally, the proceeding made its appearance in Kansas, being taken over by the territorial legislature in 1855.110 The IKansas provisions seem to have come from the revised Missouri statute of 1835 and include the same adjustment of the matter of expedition of trial. But here the career of the proceeding was even briefer than in Iowa, terminating with the adoption in 1859 of the Code of Civil Procedure, transplanted from Ohio.11 The one volume of published reports (McCahon's) dealing with the territorial period contains no instance of any resort to the statute.

The spread of the legislation in question from the State of its origin, so far as regards its installation in Alabama, Mis-

10724 Ark. 261, 263 (1866).

108 Statute Laws OF THe Territory of Iowa (1839) 380-381.

1092 G. Greene 585 (Iowa 1850).

110 Statutes OF THE T'ERRITORY OF Kansas (1855) 140-141.

211 As to the origin of the Kansas Code, see Heprurn, Historical DEvelopment of Code Pleading (1897) 104. 
souri and Mlinois, is probably accounted for by the emigration from Kentucky into these newer lands. ${ }^{112}$ In Arliansas, Iowa and Kansas, its advent, in all likelihood, was due to a less sentimental belief in its supposed advantages. But, after all, these were largely an illusion. The principal attraction of the proceeding lay in the ad captandum appeal made by its set form of petition, which invited the litigant to be his own lawyer. It did, indeed, endeavor to bring about a somewhat speedier trial than under the ordinary practice, but this was not everywhere true, and it is to be doubted whether it anywhere met with unqualified success in this regard. As against these slender merits, this same set form of petition rendered the proceeding a formalistic institution without the least possibility of adaptation to a situation at all out of the common run-an inflexible category into which the plaintiff had to fit his claim on pain of retracing his steps: in short, what we have here is a reproduction in miniature of the common law.idea of form of action at the most rigid period of its history. Moreover, there was no attempt to ameliorate the existing procedure with respect to the later pleadings. The defendant was held to the ordinary rules applicable to an action of debt. If the instrument sued on were not under seal, nil debet would suffice for most defenses; but, if the contrary were the case, then he was required to plead his defenses specially. By the same token, we can well imagine that a plaintiff suing in propria persona would find his difficulties only beginning with the coming in of the defendant's plea. The proceeding had none of the virtues of the South Carolina summary process. On the whole, it cannot be regarded as other than a well intended effort at reform, which lacked scientific value and had no claim to permanence.

\section{III}

THE VIRGINIA PROCEEDING BY NOTICE AND MIOTION OF 1849

A summary proceeding by motion for judgment based upon informal notice to the defendant, and applicable to particular situations especially calling for promptness of dispatch is to be found in numerous jurisdictions. It is, however, in certain of the Southern States-notably Virginia, West Virginia, Kentucky, Tennessee, Alabama and MIississippi-that the remedy has been more extensively used. A curious manifestation of this practice was the employment of the so-called "banl notice," in the earlier years of Alabama and IIississippi.113 This came about

112 In Curle v. McNutt, supra note 98, at 497, the court expresses its respect for the decisions of Kentucky "on a statute which we have every reason to believe was, as it were, transplanted from that State into this, for much the greater part of our population migrated thence."

113 See Logwood v. Planter's Bank, Min. 23 (Ala. 1820); Duncan v. 
from the action of the legislature in including in bank charters -as regards the former of these states apparently a usual thing -a provision ${ }^{114}$ empowering the corporation to sue its debtors,

Tombeckbee Bank, 4 Port. 181 (Ala. 1836); Levert v. Planter's \& Merchant's Bank, 8 Port. 104 (Ala. 1839); Griffin v. Bank of Alabama, 6 Ala. 908 (1844); State Bank v. Dent, 12 Ala. 187 (1847); Bank of Mississippi v. Bush, Walk. 265 (Miss. 1827).

114 A typical form of the clause in question is that appearing in Logwood v. Planters' Bank, supra note 113, at 23: "If any person or porsons shall be indebted to said Corporation as maker or indorser of any noto, bill, or bond, expressly made negotiable and payable at said bank, and shall delay payment thereof, it shall be lawful for the Corporation, after hrving given at least ten days' notice thereof, and producing to the Court beforo whom the motion is made, the certificate of the President of the Bank that the debt is really and bona fide the property of the Bank, to move for judgment against such debtor or debtors, his, her or their executors or administrators, in any court of record within the territory. Provided always, that if the defendant or defendants shall appear and contest the claim, the Court shall instanter impanel a Jury to try the issue and thorcon give judgment accordingly."

But provisions of this sort were mild compared with that which camo before the United States Supreme Court in Bank of Columbia v. Sweenoy, 2 Pet. 671 (U. S. 1829). Here it appears that by what Chief Justice Marshall refers to as "this extraordinary act," the legislature of Maryland in incorporating the Bank of Columbia in 1793 provided that, in the case of persons indebted to the bank for money borrowed, or as makers or indorsers of paper negotiable at the bank, who should mako default of payment for ten days after demand in writing, the president of the bank, by sending to the clerk of the court the instrument of indebtedness with proof of the demand, and filing his own oath or affirmation of the amount due, was authorized to require the clerk to issue "capias ud satisfaciendum, fieri facias or attachment by way of execution," subject to the right of the defendant to dispute the claim, but not until the roturn of the execution.

Quite different is the clause met with in Young v. Bank of Alexandria, 5 Cranch 45 (U. S. 1809) and Yeaton v. Same, 5 Cranch 49 (U. S. 1809). By this the legislature of Virginia conferred upon the plaintiff bank tho privilege of an expedited trial in suits by it upon bonds, bills or notes expressly made negotiable at the bank, and also permitted it, in derogation of the general law, to sue the indorser of a promissory note, without reference to the solvency or insolvency of the maker.

This favored treatment of banks as plaintiffs, at the period in question, was not confined to a particular section of the country, as witness the Rhode Island "bank process," successfully combated by Dorr, as ay member of the legislature. Under that process, we are told, "if a debtor failed to pay his note at the bank by three p. m. on the day when it became due, an attachment, judgment, execution, levy and sale might follow the same day, so that before sunset of that day such a debtor's real estate might become the property of the bank holding his protested noto, to the exclusion of the claims of all other creditors." Eaton, THomas WIISON BURR, in 5 LewIS, Great AMERICAN LAWYERS (1908) 180.

A less striking instance of the same discriminatory policy is disclosed by the Ohio statute of 1820 , permitting banks or bankers, by way of exception to the general rule, to sue jointly the drawers and indorsors of negotiable paper. See Fullerton v. Bank of United States, 1 Pot. 604 
or some class of these, by means of notice and motion, instead of the ordinary processes of the common law.125 But, whether justified or not by contemporary economic conditions, this anomalous application of the remedy has had no influence upon its subsequent history.

The manner of proceeding here in question seems to have had its origin in Virginia. As early, at least, as $1732,{ }^{110}$ statutes begin to appear in this jurisdiction providing for summary judgment on motion against sheriffs and other officers failing to pay over public moneys to the proper recipient. In 1748 , it was enacted, with reference to forthcoming bonds given on execution, that such a bond should have the force of a judgment and, if not paid, the court was empowered, "upon motion of the party to whom the same is payable, to award execution thereupon, with costs; provided the obligors have ten days notice of such motion." 117 In 1753, the sheriff or other officer failing to return an execution is subjected to a fine for the benefit of the judgmentcreditor, recoverable by motion for judgment upon 'ten days' previous notice of the motion for judgment for such fine." 210 And in 1786 occurs the more noteworthy provision-forerunner of many statutes of the same kind-that the surety who has paid a judgment rendered against him for the principal's debt may proceed against the principal by motion for judgment to recover the amount so paid. ${ }^{110}$ The same law extends the remedy also to the case of one surety, who has thus had judgment rendered against him, and is now seeking contribution from a cosurety, where the principal has become insolvent.120 Again, in 1787, the proceeding is made available to a client for the recov-

(U. S. 1828); Lewis v. Bank of Kentucky, 12 Ohio 132 (1848); Clinton Bank v. Hart, 19 Ohio 372 (1850). And for Kentucky, see supro note 77. ${ }^{115}$ In the case of the Bank of Alabama, the charter, pursuant to a clause of the Constitution of 1819, requiring the remedy for the collcetion of debts to be reciprocal, provided for proceedings by notice and motion both for and against the bank. Wrigglesworth v. Banls of Alabama, 1 Ala. 222 (1840).

116 Acts of May, 1732 , c. 10, § 8, 4 VA. STAT. (Hening) 352. This act relates to the failure of the sheriff to account to the secretary of the colony and the clerk of the county court for fees coming to his hands. Numerous later statutes prescribe the same remedy in respect of collecting officers failing to pay over the proceeds of taxes and duties. E. g., 1756, 7 VA. Stat. (Hening) 12; 1759, ibid. 263; 1761, ibid. 396; 1762, ibid. 542; (1769) 8 VA. Stat. (Hening) 346; (1775) 9 VA. Srat. (Hening) 67; 1776, ibid. 222; $c f$. Acts of October, 1705, c. 9, $\$ 9,3$ VA. Stat. (Hening) 266.

${ }^{117}$ Acts of October, 1748 , c. $12, \S 14,5$ VA. STAT. (Hening) 534.

118 Acts of November, 1753, c. 1, $\$ 25,6$ VA. STAT. (Hening) 344.

119 Acts of October, 1786, c. 15, §§ 1, 2, 12 VA. STAT. (Hening) 268.

120 Ibid. $\$ 3$. 
ery of money wrongfully withheld by an attorney. ${ }^{121}$ It is not here in place to review in detail the progress of this legislation; suffice it to say that as time went on the remedy was applied to other situations with such generosity that the first edition of Robinson's Practice (1832) enumerates some twenty-five categories in which it is at a plaintiff's command.122 With respect to the proceeding itself, the author observes:

"In various cases the legislature have authorized judgment to be entered and execution to be awarded, upon motion, in a summary way $* * *$. In giving these summary remedies, the legislature always provide that the party proceeded against shall be given notice of the motion, for ten days, or some reasonable time $* * *$. In motions upon forthcoming bonds. and replevy bonds, it is very common to give notice ore tenus. In other motions it is usual for the plaintiff to write a notice to the defendant, of the intended motion; and this written notice is returned to the court in which the motion is made, with an affidavit shewing that a copy thereof has been duly delivered." ${ }^{123}$

As it was in Virginia that the proceeding had its inception, so it was here that it took on an entirely new significance. This occurred in 1849, at the instance of the revisers whose labors culminated in the Code of that year. In their report they informed the legislature, that

"by this mode of proceeding, all claims of the Commonwealth, and a large number of those of individuals are now recoverable; yet a formal point scarcely ever arises upon a motion. The case is very generally decided upon its merits. A brief notice serves the double purpose of a writ and a declaration; .and though a defendant is not precluded from pleading, yet as the case can be heard without pleading, pleadings are in fact very rarely filed. Seeing that this mode of proceeding has worked well in the cases in which it has been heretofore allowed, it seems to us advisable to extend it to all cases in which a person is now entitled to recover money by action on a contract. We do not propose to take away the right of bringing an action from any person; we propose merely, when his claim to money is on a contract, to allow him to use, if he please, the more simple remedy by motion, instead of an action. The permission to proceed in this way will, we believe, cause motions gradually to take the place of actions for all such claims." ${ }^{124}$

The result was the inclusion in the Code of 1849 of certain sections appropriate to this purpose. It was provided that:

\footnotetext{
121 Acts of October, 1787 , c. 10, § 3, 12 VA. STAT. (Hening) 473.

222 Pp. 589-621.

123 P. 589.

124 Report of Revisers, cited in Wilson v. Dawson, 96 Va. 687, 691 (1899). See also barton, Practice in the Courts of LaW in Civil Cases (1877) 333.
} 
"any person entitled to recover money by action on any contract, may, on motion $*$ obtain judgment for such money after sixty days' notice, which notice shall be returned to the clerk's office of such court forty ddays before the motion is heard." 125

And further that:

"on a motion when issue of fact is joined, and either party desire it, or when, in the opinion of the court it is proper, a jury shall be empanneled, unless the case be one in which the recovery is limited to an amount not greater than twenty dollars, exclusive of interest."

In this form the statute remained until 1887, when by the revision of that year the time of notice was cut down to fifteen days with modification, also, of the post-return period, it now being provided that the notice should be returned ten days before the commencement of the term. ${ }^{128}$ In 1S96, a provision was included extending to this form of proceeding the requirement of an affidavit of merits from the defendant in case of affidavit of claim made by the plaintiff. ${ }^{12 s}$ But by 1912 the remedy had attained such additional growth in favor as to call for a further enlargement of its scope. By a process of amendment beginning in that year, it was made applicable to actions of tort, ${ }^{120}$ to actions on contracts not previously falling within its sphere, ${ }^{123}$ to actions for statutory penalties ${ }^{131}$ and to actions for the recovery of specific personal property or damages in lieu thereof.132 This movement had its logical outcome in the revision of 1919, by which the remedy became available for common law actions in general, through the provision that "any person entitled to maintain an action at law may, in lieu of such action, proceed by motion." 133

After 1887 the proceeding also underwent some re-regulation with respect to its time requirements. Thus, by the amendment of 1896, there ceased to be any appointment of a secondary or post-return period, or any necessity of return in advance of the hearing term: the substituted provision was that the notice should be returned within five days after service and should be

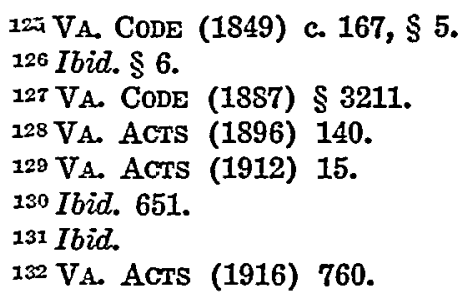

$133 V_{A}$ CODE (1919) $\$ 6046$. For a fuller account of the amendments leading up to the enactment of this provision, see Revisers' Note to the section in question. 
docketed upon the lapse of the notice-period. ${ }^{13}$ And, when in 1912, the remedy was extended to actions of tort, thirty days' notice was here prescribed, instead of the usual fifteen. ${ }^{100}$ But now, under the revision of 1919 and the further amendment of 1922, the notice-period for all cases of the general proceeding, is one of at least fifteen days and ordinarily not more than ninety days; return of the notice continues to be called for within five days after service; but the cause is now docketed on the returnday, that is to say, the day named in the notice for the making of the motion. ${ }^{138}$

With respect to the form of the defendant's allegations, it has been seen that, under the practice prior to the Code of 1849 , there was no duty resting upon him to put these in writing. For nearly half a century thereafter there was no pronouncement on the part of the Supreme Court or the legislature in any way at variance with this idea. Indeed, on more than one occasion the court, at least by way of dictum, had expressly recognized the right of the defendant to plead ore tenus in this mode of proceeding. ${ }^{137}$ Nevertheless, it appears to have been a fairly prevalent custom to file formal pleas as in an ordinary action or else "the trouble is usually solved by the plaintiff calling for a statement of the grounds of defense" under the general provision relating to bills of particulars. ${ }^{138}$ In 1895 , however, this

134 Va. Acts (1895-1896) 140; M. P. BurKs, Pleading and Practicn IN ACTIONS AT Common LAW (1st ed. 1913) 164-165. By the revision of 1887 , as above appears, the notice was to be returned ten days before the term. Under the Code of 1849 , although this was silent as to the time of the return with relation to the commencement of the term, requiring only that the notice be returned forty days before hearing, it was held that this return had to be in advance of the opening of the term: in other words, that the cause had to be "matured for the docket before the term." Halo v. Chamberlain, 13 Gratt. 658 (Va. 1857), as interpreted by Hanks v. Lyons, 92 Va. 30 (1895).

135 VA. ACTS (1912) 15.

${ }^{180}$ VA. CoDE (1919) § 6046; VA. ACTS (1922) 763; Morrissett, Logislation of 1922 (1922) 8 VA. L. REG. (N. S.) 81, 97-98. The ninety day maximum may be exceeded where the next term does not commence within ninety days from the date of service.

137 See Cecil v. Early, 10 Gratt. 198, 202 (Va. 1853) ; Supervisors v. Dunn, 27 Gratt. 608620 (Va. 1876); Bunch's Ex'rs v. Fluvanna County, 86 Va. 452, 454 (1890); see also Pairo v. Bethell, 75 Va. 825, 830 (1881). Hall v. Ratliff, $93 \mathrm{Va} .327$ (1896), decided after Preston v. Salem Improvomont Co., infra note 139, and without reference to the holding in the latter, is to the same effect.

138 M. P. Burks, Note to Wilson v. Dawson (1899) 4 VA. L. REG. 753. Seo also Bunks, op. cit. supra note 134, at 174. Under date of 1892 it is said: "The statute of Virginia prescribes no mode of pleading by which the defence to a motion may be presented to the court, but it is a commendable practice which prevails in some of the circuits to require the defendant either when he enters his appearance, or at some reasonable time thereafter, to put in writing in sufficiently explicit terms the grounds 
practice was materially affected by the decision of the Supreme Court in Preston v. Salem Improvement Co. ${ }^{159}$ It was here held, in a suit by motion to recover money due on contract, that the right to a jury trial existed only, according to the statute, "where an issue of fact is joined," 140 and that before there could be a joinder of issue, there must be written allegations on the part of the defendant. But, for this purpose, the court indicated that, as an alternative to the common law plea or pleas appropriate to the action, it was open to the defendant to employ an "informal statement in writing."

"As the object of this proceeding by motion under section 3211 ," said the court, "was to give suitors a plain and summary proceeding for the recovery of judgments, and it is but in accordance with the spirit of this flexible proceeding by motion to permit the defendant to make his defense by such informal pleas or statement in writing as will state his defense and make up the issue to be tried, this latter practice is permissible, except in all cases where the statute requires the plea to be verified by affidavit."

This interpretation has since been accepted by the legislature and transformed into a rule applicable to the proceeding whether the trial is by jury or by the court alone; the revision of 1919 specifically declares that

"the defendant may make the same defenses to the notice as to a declaration in an action at law, and in the same manner, or he may state his grounds of defense informally in writing, and in the latter event the parties shall be deemed to be at issue on the grounds stated without replication on the part of the plaintiff." 142

There can be no doubt that an important element operating in favor of the remedy is the sympathetic consideration which it has received at the hands of the courts from the earliest period of its history. In 1797 , speaking with reference to a proceeding by motion instituted by a sheriff against his deputy and the sureties of the latter, to recover execution-moneys not accounted for, Roane, J., said:

"I am strongly inclined to view notices with indulgence, seeing that they are the acts not of lawyers but of the parties." 212

upon which he rests his defence to a motion for judgment for money." 2 barton, Practice in the Courts of the lati in Civm Cases (2d ed. 1892) 1047.

13991 Va. 588 (1895).

110 VA. CODE (1887) § 3213.

${ }^{141}$ VA. CODE (1919) $\S 6046$. Where there is a general denial of the plaintiff's claim, "Tike other general issues, it may be pleaded orally, but all other defenses must be set up in writing." Duncan v. Carson, $127 \mathrm{Va}$. 306,313 (1920).

142 Drew v. Anderson, 1 Call 50, 52 (Va. 1797). 
This became the settled canon of construction. The foregoing expression was reiterated and expanded in Supervisors $v_{\text {e }}$ Dunn (1876) ${ }^{143}$ in the following terms:

"The rule governing notices is that they are presumed to be the act of the parties and not of lawyers. They are viewed with great indulgence by the courts; and if the terms of the notice be general, the court will construe it favorably, and apply it according to the truth of the case, as far as the notice will admit of such application. If it be such that the defendant cannot mistake the object of the motion, it will be sufficient." 144

In the latter case, as in the former, the motion was one under a special statute, but the same doctrine unreservedly obtains wherever the proceeding is used.

"A proceeding by motion under Virginia Code (1904) sec. 3211," said the court in Whitley v. Booker Bricle Co. (1912) $)^{140}$ "is intended to furnish a simpler, more expeditious, and less expensive remedy for the collection of debts than by action, and the same is true of motions generally. Hence, we find that the uniform course of decision in this State has been to view with more leniency and to allow greater laxity in the pleadings in that form of procedure." ${ }^{146}$

On the other hand, "this does not relieve the plaintiff of the requirement that he set out in his notice to the defendant mattor sufficient to maintain the action, and whether or not he has done this is the sole question raised by the demurrer to the notice." $14 t$ Nor is it open to the plaintiff to allege one thing and prove another: "the rule that the allegata and probata must correspond is likewise applicable to proceedings by way of motion." $14 \mathrm{~s}$

The gain from the use of this proceeding is not confined to its doing away with the formal writ and its simplification of the pleadings. Under the Virginia practice as to terms of court,

\footnotetext{
15327 Gratt. 608, 612 (Va. 1876).

144 Citing Graves v. Webb, 1 Call 443 (Va. 1797); Segouino v. Auditor, 4 Munf. 398 (Va. 1815) ; Steptoe v. Auditor, 3 Rand. 221 (Va. 1825).

145113 Va. 434, 436 (1912).

140 Accord: Rinehart v. Pirkey, 126 Va. 346, 352 et seq. (1919) ; Shreck v. Va. Hot Springs Co., 140 Va. 429,432 (1924). But the presumption originally underlying the doctrine seems to have been discarded. "The proceduro by notice under section 6046 of the Code is looked upon with great indulgence, not because the notice is supposed to be the act of a layman ignornnt of forms of law, for that would be contrary to almost universal experience, but because the courts are loath to sacrifice substance to form and desire, so far as possible, to avoid that result." Per Burks, J., in Mankin v. Aldridge, $127 \mathrm{Va}$. 761, 767 (1920).

${ }_{147}$ Security Loan Co. v. Fields, 110 Va. 827, 829-830 (1910). Accord: Matthews v. La Prade, 130 Va. 408, 413 (1921); Wessel v. Bargamin, 137 Va. 701, 707 (1923).

148 Burks, Pleading and Practice, at 170.
} 
it enables the plaintiff to move more rapidly than would otherwise be possible.

"The second and chief advantage," says the author of the standard work on modern Virginia common law practice, "is that you may proceed by motion when it is too late to mature a regular action, or even after a term of court has begun, if it shall continue in session long enough for this purpose, as many of the city courts do. It requires two sets of rule days to mature a regular action, but you may proceed by motion, as just stated, after either or both sets of rule days have passed, and if there is time enough to give the requisite notice, may thus proceed to obtain judgment by motion when it will be too late to obtain it by a regular action." 140

The success of the remedy is plainly attested by the pains recently taken for its extension and improvement, as well as by the numerous cases in the court of review in which the plaintiff has elected to utilize it. That success, moreover; is unqualified. In 1895, when the general proceeding was still confined to actions on contracts, we find it stated by competent authority "that in plain cases the summary remedy by motion has almost superseded the common law forms of action for the recovery of debts." 150 Since its extension in 1919, while it has not as yet dislodged the other common law actions to the same degree, it has made constant and increasing inroads upon their province. ${ }^{151}$ The probability is, therefore, that in time there will occur in Virginia what has happened on sundry occasions in the history of procedure on the Continent of Europe, namely, that the summary procedure has become the ordinary one.

But the career of the remedy in Virginia does not tell the whole story. For, with other Virginia institutions, the proceeding by motion found place in the legislation of West Virginia. The latter's first Code, that of 1870, besides putting it at the plaintiff's disposal in sundry single instances, reproduced verbatim the contemporary Virginia provisions with reference

149 Ibid. 168.

150 E. C. Burks, Note to Hanks v. Lyons (1895) 1 VA. L. REv. 441.

15. "I can confidently say * * that the summary proceeding, by notice and motion, under the Virginia statute, is popular with the Virginia bar, and that it is much used. It has been more used, certainly, since the remedy has been extended to any action at law. It is more popular with some attorneys than with others, and in some localities than in other localities. I think I can say, however, that whenever an attorney finds that he has a case in which he must drav his declaration with extreme care in order to avoid a troublesome demurrer, he will relieve himself of some of his uneasiness by filing his notice and motion. I thinl: the statute has been altogether beneficial and a great boon to lawyers who desire to avoid the pitfalls of common law pleadings." President Prentis of the Supreme Court of Appeals, in letter to the present writer. under date of November 19, 1927. 
to its general use in actions on contracts to recover money. There was added, however, the declaration that "defense to such motions may be made in the manner and to the same extent as in actions at law." ${ }^{152}$ In 1882, the statute was amended so as to shorten the period of notice and the period which must elnpse between the return of notice and the hearing, from the original sixty and forty days, respectively, to thirty and twenty days. ${ }^{100}$ By further amendments, adopted in 1915, these periods were again abridged, the former to twenty and the latter to fifteen days, and provision was made for affidavit of claim and affidavit of merits as in the ordinary procedure. ${ }^{154}$ Meanwhile, it had been necessary that the notice be returned in advance of the hearing term; ${ }^{155}$ but in 1925 this rule was changed and brought into substantial alignment with the later Virginia rule by the provision that the motion "may be commenced and matured during the term $* * *$ and may be heard at the same term," if this has not expired before the lapse of the notice-period. ${ }^{150}$ Thus, the remedy, in West Virginia, apart from special instances, remains limited to cases where the plaintiff "is entitled to recover money by action on any contract." 157

In dealing with the sufficiency of the notice, the West Virginia courts follow the Virginia doctrine which accords its contents a liberal construction, ${ }^{158}$ but contemplates the statement of a good cause of action. ${ }^{150}$ Its purpose is said to be that of acquainting the defendant with the grounds on which the plaintiff proposes to proceed against him, and "all that is required in such notice is that it should be so plain that the defendants cannot mistake the objects of the motion, however it may be wanting in form and technical accuracy." 100 The means commonly employed to question the sufficiency of the notice is a motion to quash, rather than a demurrer as used in Virginia, but its operation is precisely the same. ${ }^{101}$ Concerning the mode of pleading defenses, it may be said that the statutory provision in this regard, namely, that defense "may be made in the same manner and to the same extent as in actions at law" has not

152 W. VA. CODE (1870) c. $121, \S \S 6-8$, p. 593.

153 W. VA. ACTS (1882) 171.

154 W. VA. ACTS (1915) 449.

${ }^{155}$ Knōx v. Horner, 58 W. Va. 136 (1905); Citizens' Nat. Bank v.

Dixon, 94 W. Va. 21 (1923).

150 W. VA. ACTS (1925) 283.

157 W. VA. CoDE ANN. (Barnes, 1923) 2133-2135.

158 Board of Education v. Parsons, 22 W. Va. 308 (1883).

152 Hastings v. Grump, 89 W. Va. 111 (1921); Anderson v. Prince, 60

W. Va. 557 (1906).

160 Shepard v. Brown, 30 W. Va. 13, 19 (1887). Accord: Stuart v. Carter, 79 W. Va. 92 (1916); People's State Bank v. Jeffries, 99 W. Va. 399 (1925).

101 Jennings v. Wiles, 82 W. Va. 573 (1918). 
resulted in any material difference from the existing Virginia practice. This provision, said the Supreme Court of Appeals in 1911,

a $: *$ is permissive, not mandatory. It was passed long after the character of the proceeding by motion had been judicially established. It says, not that defense shall be made in the same manner as in actions at law, but that it may be so made. $\forall * *$ The old common law rule, making a plea and joinder of issue essential to the trial of a case is still adhered to by this Court, in common law actions, but is always reluctantly applied, when it appears that the parties have treated the issues as having been made up and fully submitted their respective claims and contentions to the jury. If it were possible, consistently, to avoid reversals for such cause the Court would cheerfully do so. It looks upon the rule with great disfavor. ${ }^{162}$ Hence, we are not disposed to extend it to summary and informal pioceedings in which it has not hitherto been applied. Substantial justice requires statements of the nature of the demand and the defenses, sufficient to give each of the parties notice of what is asserted against him and constitute a basis for the introduction of evidence; but it does not require any particular formality in them. It is enough that the respective claims and contentions of the parties are put into the record."

This is virtually the same rule as under the Virginia statute of 1919.

Concededly, the progress of the remedy has been slower here than in Virginia. Not only has legislation in respect of its scope halted with adoption of the Virginia provision of 1849, but even in the case of the contract actions for which it was thus made available, its employment has not been as extensive as in the older State. Nevertheless, this employment is on the increase, and at present approximately half the number of these actions are brought in the summary form. Moreover, since the Virginia amendment of 1919 attempts have been made to obtain here the adoption of a similar statute. In view of the growing favor which attends the remedy, the prospects are that this manner of legislation will not be long deferred. For West Virginia, therefore, it is apparently but a question of time until the remedy attains a success equal to that which it has already achieved in Virginia. ${ }^{164}$

\footnotetext{
162 Citing Simpkins v. White, 43 W. Va. 125 (1897).

163 Collins v. White Oak Fuel Co., 69 W. Va. 292, 295 (1911).

10A These statements are based upon information received from the Hon. Harold A. Ritz of Charleston, W. Va., formerly one of the judges of the Supreme Court of Appeals. Specifically, Judge Ritz says, in a letter to the present writer, under date of November 25, 1927: "For many years, this form of action was not very much used in West Virginia. In the last few years, however, it is coming into very much more general use. The younger members of the bar, I believe, are using it in most cases where it is applicable, and it is entirely probable that in the next few
} 
years it will practically supersede the common law actions for the recovory of debts in this State, as it has in Virginia. There have been efforts in the Legislature to make the same form of action apply to causes of action arising out of tort, and no doubt this will be done as tho bar becomes more familiar with the use of the remedy. There is no renson why it should not be made to apply to tort actions, if the cause of action be fairly stated in the notice. *** I should say that in perhnps flfty per cent of the ordinary contract actions, this form is used in this Stato at this time, and I have no doubt it will become more popular as it becomes more familiax." 